\title{
Separation of Thoracoomphalopagus Conjoined Twins. Use of Tissue Expanders and Abdominoplasty According to the San Martín Technique.
}

Boglione Mariano ${ }^{1 *}$, Reusmann Aixa ${ }^{1}$, Aleman Santiago ${ }^{2}$, Rodríguez Paula ${ }^{2}$, Strambach Julieta ${ }^{1}$, Médici Walter ${ }^{3}$, Schaigorodsky Lorena ${ }^{3}$, Dacoff Héctor ${ }^{3}$, Arbio Soledad ${ }^{4}$ and Barrenechea Marcelo ${ }^{1}$.

${ }^{1}$ General Surgery Division, Hospital de Pediatría Prof. Dr. Juan P. Garrahan. Buenos Aires. Argentina.

${ }^{2}$ Plastic and Reconstructive Surgery Division, Hospital de Pediatría Prof. Dr. Juan P. Garrahan. Buenos Aires. Argentina.

${ }^{3}$ Anestesiology Division, Hospital de Pediatría Prof. Dr. Juan P. Garrahan. Buenos Aires. Argentina.

${ }^{4}$ Neonatal Intensive Care Unit, Hospital de Pediatría Prof. Dr. Juan P. Garrahan. Buenos Aires. Argentina.

*Corresponding Author: Boglione Mariano, General Surgery Division, Hospital de Pediatría Prof. Dr. Juan P. Garrahan. Buenos Aires. Argentina.

Received date: February 08, 2021; Accepted date: February 17, 2021; Published date: February $23,2021$.

Citation: Boglione Mariano, Reusmann Aixa, Aleman Santiago, Rodríguez Paula, Strambach Julieta, Médici Walter, Schaigorodsky Lorena, Dacoff Héctor, Arbio Soledad, and Barrenechea Marcelo. Separation of Thoracoomphalopagus Conjoined Twins. Use of Tissue Expanders and Abdominoplasty According to the San Martín Technique, J. New Medical Innovations and Research, 2(1): DOI: 10.31579/jnmir.2021/005.

Copyright: () 2021 Boglione Mariano. This is an open-access article distributed under the terms of The Creative Commons Attribution License, which permits unrestricted use, distribution, and reproduction in any medium, provided the original author and source are credited.

\begin{abstract}
We present a set of female thoracoomphalopagus conjoined twins who were separated at ten months of age. Tissue expanders were used to expand the available soft tissue to cover the defect. The abdominal wall was closed by making a release incision on the outer aspect of the anterior sheath of the rectus muscle, detaching the anterior sheath off the muscle fibers, and flipping it over towards the midline. Meshes of decellularized collagen matrix were use to close the thorax.

They had no major complications and were discharged from the hospital 60 days later.

The girls are currently 5 years old, and lead a normal life according to their age.

We believe that the use of tissue expanders combined with the mobilization of aponeurotic flaps through discharge incisions adds a useful tool for the treatment of these patients.

Keywords: conjoined twins,thoracoomphalopagus, abdominoplasty, expanders
\end{abstract}

\section{Introduction}

There are two types of twin pregnancy: dizygotic or fraternal, which represent $70 \%$; and monozygotic, which are around $30 \%$. Sometimes monozygotic twins persist together in some segment after 13 days of embryonic development, and so-called conjoined twins develope, which are classified according to the anatomical region that joins them [1]. Thoracic are the most frequent (40 to $75 \%$ ), then omphalopagus (15 to $33 \%$ ), ischiopagus (6 to $10 \%$ ) and cephalopagus (2\%). They are of the same sex and genetically identical. Its frequency varies between 1 in
200,000 to 1 in 40,000 births, and occurs in women and men in a ratio of 3 to $1[2-4]$.

We present a case of female thoracoomphalopagus conjoined twins who were separated at ten months of age.

\section{Case report}

Female thoracoomphalopagus conjoined twins born by elective caesarean section at 36.6 weeks of gestation with a joint weight of 3,840 grams from a 27 -year-old mother (Figure 1). Diagnosis was made in the prenatal period by ultrasonography and magnetic resonance imaging. 


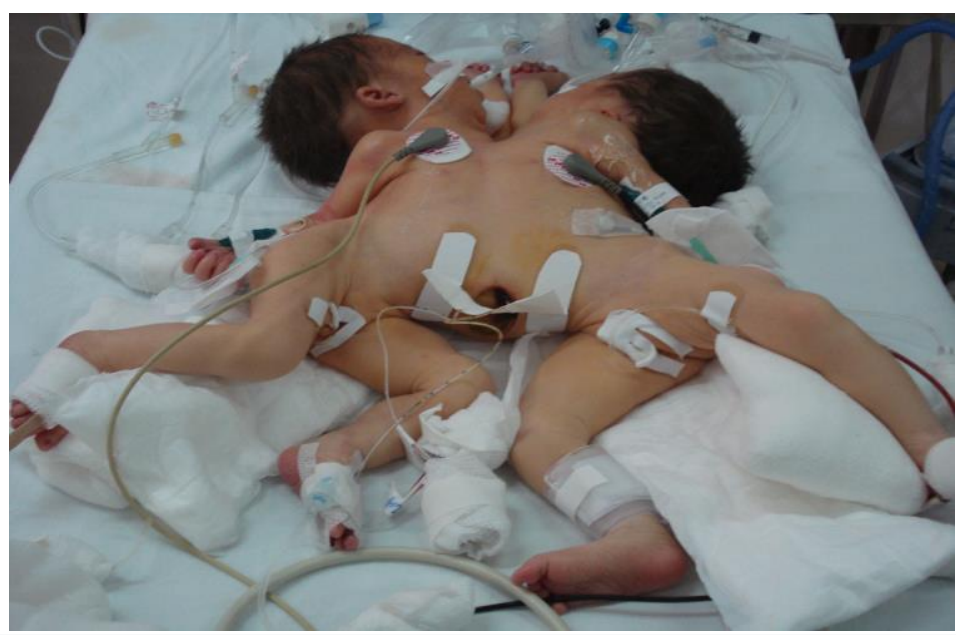

Figure 1: Toracoomphalopagus conjoined twins the first day of life.

After birth, a brain ultrasound was performed on both girls, which was normal. Echocardiography showed a single pericardial cavity with two hearts in it, without being able to define whether or not they shared ventricular myocardial wall. Abdominal ultrasound observed 4 kidneys, 2 bladders and one liver fused in the midline that passed from one girl to the other. Two hepatic pedicles were identified in the liver, each consisting of a normal bile duct, hepatic artery, and portal vein. Two suprahepatic venous drainage systems were also observed.
Computed tomography angiogram scan (Figure 2) showed a single pericardial cavity, with two hearts inside. From each heart an aorta emerged that supplied the rest of the body of each twin, and the venous return was effected through a vena cava for each girl. The liver fused in the midline with two independent vascular and biliary pedicles. Four kidneys forming two independent urinary systems. Each sister had a separate digestive system (esophagus, stomach, small and large intestine). Barium contrast study through a nasogastric tube was performed to verify gastrointestinal anatomy.

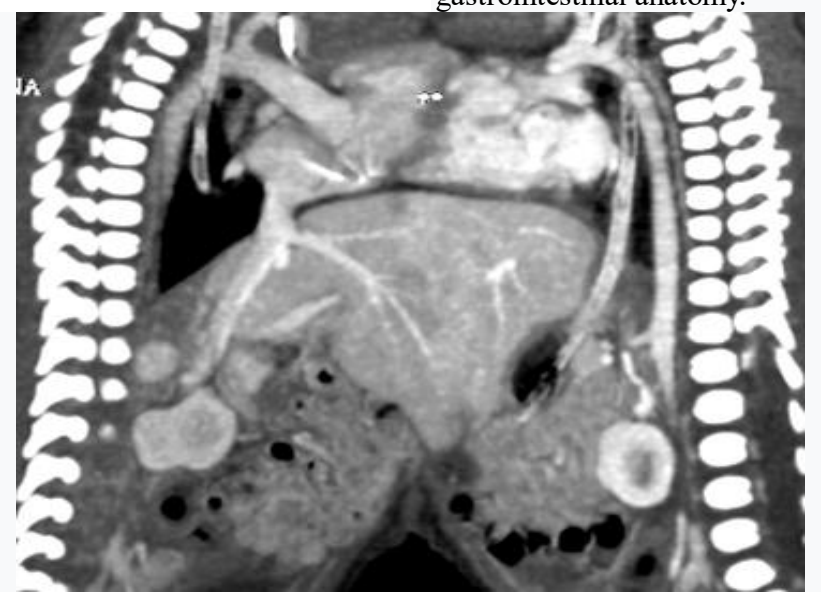

Figure 2: CT scan showing two hearts in a single pericardial cavity and a fused liver.

The thorax was made up of two rib cage with rectified ribs that approached 2 sternum outlines (located one on each side), which faced the rectified ribs of the other twin (Figure 3).

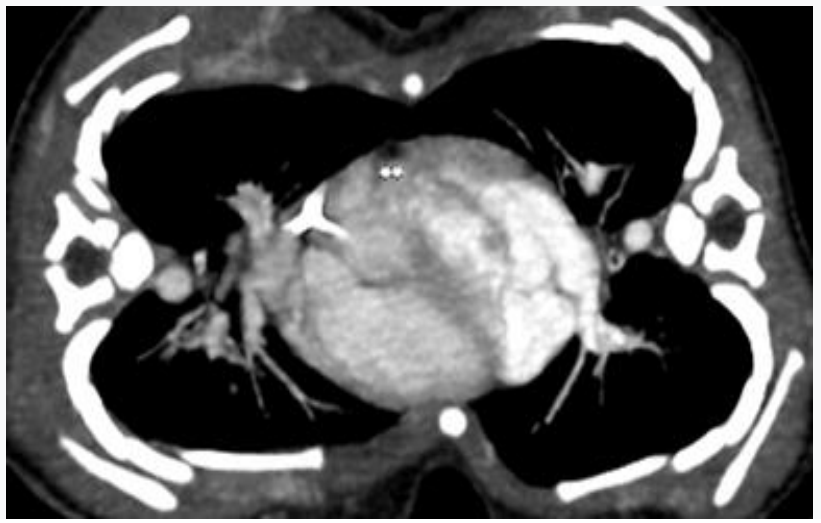

Figure 3: CT scan. Chest wall. 
Due to the fact that the girls were hemodynamically compensated without the need for any type of medical support, it was decided to delay separation to allow the placement of tissue expanders with the aim of increasing the amount of skin and subcutaneous cellular tissue available for wall closure.

At 9 months of age, 2 expanders of $160 \mathrm{cc}$ each were placed on each shoulder, with the valves externalized by counter-opening. Thirty-five days after placement, it was observed that one of the expanders began to extrude, so it was decided to separate the girls. This was performed 6 days later.

\section{Surgical Technique:}

Skin flaps were designed and tisuue expanders were removed. A longitudinal skin incision advancing over expanded tissue and a median laparotomy up to the umbilicus, sectioning it in its midline, were performed. The sternum was identified and was sectioned through the midline. Both pleural cavities were opened and phrenic nerves identified. The thymus was dissected free and the single pericardial cavity was incised, observing complete separation of both hearts. The diaphragm and posterior surface of the pericardium were dissected and sectioned. Both hepatic hila were identified and the liver was sectioned using electrocautery and ultrasonic sealer (Focus $\left.{ }^{\circledR}\right)$. Hemostasis of liver surface was done with argon gas (Force Fx, Medtronic $\AA$ ). The other sternum (posterior) was incised and then posterior soft tissues were sectioned (Figure 4).

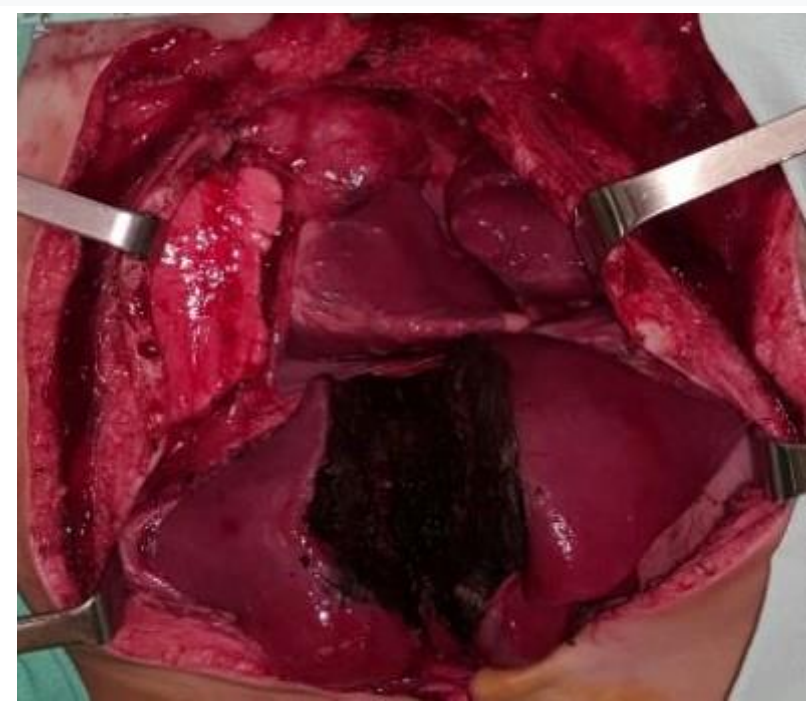

Figure 4: Both hearts into a single pericardium, and liver sectioned surface.

The abdominal wall was closed by making a release incision on the outer aspect of the anterior sheath of the rectus muscle, detaching the anterior sheath off the muscle fibers, and flipping it over towards the midline; according to the San Martín technique.

Due to the inability to approximate both edges of the rib cage, a decellularized collagen matrix mesh (Surgisis ${ }^{\circledR}$ ) was placed, attached to both sternal bars with separate braided polyester stitches (Ethibond $($ ) and a second reinforcement suture of the same material.

Closure of subcutaneous tissue flaps were done with $3 / 0$ polyglycolic acid (Polisorb ${ }^{\circledR}$ ) and skin was closed using $4 / 0$ nylon stitches.

Blake ${ }^{\circledR} 19$ type drains were left in both pleural spaces; and Blake ${ }^{\circledR} 15$ drains were left inside the abdomen and at subcutaneous tissue.

Both patients received inotropic support for the first 4 postoperative days. They were on mechanical ventilation (MV) for 15 days and non-invasive ventilation (NIV) for another 13 days.

They had no major complications and were discharged from the hospital 60 days later.

The girls are currently 5 years old, and lead a normal life according to their age.

\section{Discussion}

Treatment of conjoined twins generates complex ethical dilemmas since the fact of sharing anatomy implies risks of loss of organs or functions, or even life, during separation. This is not always the same for both twins, and sometimes forces physicians to choose between favoring one or the other [5].

Monozygotic twins constitute a deviation from embryological development, because some factor, at a given moment, produces the division of the product of conception. The moment of development at which this division occurs is the factor on which the morphology of the fetuses and the placenta ultimately depends. The division can occur from the second to the fifteenth to sixteenth days after fertilization. Therefore, if the separation takes place before or on the third day (in the 2-cell stage, prior to the development of the inner cell mass), the development potential is complete. In such a situation, two embryos are formed with their corresponding chorion and amnion, that is, a biamniotic and bichorionic gestation occurs.

By the fourth to seventh days after fertilization, the inner cell mass has formed and the outer cells have differentiated into the chorion; the amnion is not yet differentiated, so division at this stage produces 2 embryos, each with its own amnion and covered by a single chorion (ie, a monochorionic and bi-amniotic pregnancy). Finally, if the duplication occurs after the eighth day after fertilization, when the trophoblastic cells have differentiated into a single amnion, the pregnancy is monoamniotic and monochorionic; the embryonic disc divides and develops into two complete embryos within a single amniotic sac.

Division of the embryonic disc at any time of development after the date of formation of the embryonic axis, around days 13 to 15 after fertilization, produces incomplete separation of the embryos. In such a situation, conjoined twins are formed in the same amniotic sac. The binding site can correspond to any embryonic pole [6-8]. 
Another theory holds that conjoined twins result from the secondary union of two originally separate monoovular embryonic discs. During the third or fourth week of embryonic development, the previously separated embryonic discs are reattached dorsally (craniopagus, spinal, pygopagus), ventrally (cephalopagus, thoracopagus, omphalopagus, ischiopagus, parapagus) at sites where the ectoderm is absent or open. These areas include heart, diaphragm, oropharynx, cloacal membranes, neural tube, and the periphery of the embryonic discs [9].

Regarding the optimal moment of separation, bearing in mind that the girls were hemodynamically compensated, feeding orally, and without the need for any type of medical support, we understood that there was no urgency to separate them, so we decided to let them grow for a few months [10].

Because we anticipated insufficient integuments to cover the very large defects that would remain in both patients after separation, we agreed to place tissue expanders on each side of the medial junction area to expand the amount of skin and subcutaneous cellular tissue available [11, 12]. We decided to place the expanders at 9 months of age in order to wait for an increase in the thickness of the subcutaneous cellular tissue that could prevent decubitus and extrusion. Despite this, 35 days after being placed, one of the expanders began to extrude, so it was decided to perform the separation at that time.

The operating room was organized with two anesthesia machines and their respective ventilators, and two complete surgical teams (surgeons and scrub nurses) were arranged. Likewise, as we had not been able to determine whether the girls shared ventricular heart muscle or not, two extracorporeal circulation (cardiopulmonary by-pass) pumps were prepared in case were necessary.

Once the girls were separated on, a very large thoracoabdominal surface was left in each of them. Therefore, to closure the abdominal muscle wall, we used the technique of flipping over towards the midline the anterior sheath of each rectus muscle, as described by San Martín [13]. We had successfully used this technique to repair large abdominal hernias secondary to epithelialization of the amniotic membrane in patients with giant omphalocele [14].

When bringing the sternal edges closer, they compressed lungs and heart, so we decided to place a prosthesis (mesh) made of decellularized collagen tissue derived from the submucosa of the pig intestine (Surgisis ${ }^{\circledR}$, Cook Medical). We chose this mesh because it is biodegradable. Other authors report the use of similar meshes, both biodegradable and non-absorbable [15-17].

Both the abdominal muscle wall and the meshes (prosthesis) were seamlessly covered with expanded subcutaneous skin and tissue.

Prenatal diagnosis is important since it allows to study these patients at this stage, searching and detecting associated malformations; and also allows determining the characteristics of shared structures. This information is useful to support parents, instruct them on the prognosis of these children, and to program and plan neonatal management in a tertiary care center $[18,19]$.

The only indication of emergency separation is when one of the twins is dying or already dead and an attempt is made to maintain the life of the other. Undoubtedly, emergency separation has a high mortality rate, which decreases with coordinated and planned separation. Those that require emergency separation have survival ranges of 30 to $50 \%$. Scheduled surgery raises the survival range from 80 to $90 \%$ [20, 21]. Although in our case we had to advance the separation due to the extrusion of one of the expanders, this did not imply risk of life for them and they were always hemodynamically compensated.
We believe that the use of tissue expanders combined with the mobilization of aponeurotic flaps through discharge incisions adds a useful tool for the treatment of these patients.

\section{References}

1. American College of Obstetricians and Gynecologists Committee on Practice Bulletins Obstetrics, Society for Maternal-Fetal Medicine, ACOG Joint Editorial Committee ACOG Practice Bulletin 56: Multiple gestation: complicated twin, triplet, and high-order multifetal pregnancy. Obstet Gynecol 2004; 104 (4): 869-883.

2. León PJA, Fernández SG, Araoz AJ (2011). Thoracoonfalópagos in the National Institute of Pediatrics Cir Plast; 21 (3): 160-165.

3. Endres L, Wilkins I (2005). Epidemiology and biology of multiple gestations. Clin Perinatol; 32 (2): 301-314.

4. Spitz L, et al. Conjoined Twins. JAMA. 2015; 289 (10): 1307- 10. doi: 10.1001 / jama.289.10.1307

5. A. Trull, A. Pam-Pino, R. Arrieta-García, E. Angulo-Cebada, M. Paz-Román (2010). Siamese thoracopagus. Case presentation. Rev Cubana Genet Comunit, 4, pp. 51-54.

6. Kaufman MH (2004). The embryology of conjoined twins. Child's Nerv Syst; 20 (8-9): 508-25. https://doi.org/10.1007/ s00381-0040985-4

7. Spencer R (2000). Theoretical and analytical embryology of conjoined twins: Part I: Embriogenesis. Clin Anat. 2000; 13 (2): 97-120. https://doi.org/10.1002/(SICI)1098-2353, 13: 23.0.CO; 2I

8. Spencer R (2000). Theoretical and analytical embryology of conjoined twins: Part II: Adjustments to union. Clin Anat. 2000; 13 (2): 97-120. https://doi.org/10.1002/(SICI)1098-2353, 13:23.0.CO;2-I

9. González Cortés B, Hernández M (2015). Thoracópagus Siamese twins: case presentation and literature review. Perinatology and $\begin{array}{llll}\text { Human } & \text { Reproduction; } 29 & \text { (3): } & \text { 130-133. }\end{array}$ https://doi.org/10.1016/j.rprh.2015.12.006

10. Mutchinick OM, et al (2011). Conjoined twins: A worldwide collaborative epidemiological study of the International Clearinghouse for Birth Defects Surveillance and Research. Am J Med Genet

1. Part C Semin Med Genet; 157 (4): 274-287. https://doi.org/10.1002/ajmg.c.30321

11. Sandoval-Martínez DK, Centeno-Hurtado KT (2017). Presentation of a case of cephalopagus conjoined twins. Rev Cuba Obstet and Ginecol; 43 (2): 1-8.

12. Zucker RM, Filler RM, Roopnarine L (1986). Intraabdominal tissue expansion: an adjunct in the separation of conjoined twins. J Pediatr Surg; 21 (12): 1198-1200.

13. San Martín A (1948). Technique for the treatment of large supraumbilical medium eventrations. Anatomo-physiological procedure. Bulletins of the Argentine Academy of Surgery 32: 328-336.

14. Boglione M, Aleman S, Reusmann A, Rubio M y Barrenechea M (2021). Giant omphalocele: delayed closure using the San Martín technique following epithelialization of the membrane. J Pediatr Surg. In press . DOI: https://doi.org/10.1016/jpedsurg.202.01.016.

15. Kelly DA, et al (2009). Pelvic and abdominal wall reconstruction using human acellular dermis in the separation of ischiopagus tripus conjoined twins. Ann Plast Surg; 62 (4): 417-420.

16. Dasgupta R, Wales PW, Zuker RM, Fisher DM, Langer JC (2007). The use of Surgisis for abdominal wall reconstruction in the separation of omphalopagus conjoined twins. Pediatr Surg Int; 23 (9): 923-6. doi: 10.1007 / s00383-007-1909-7.PMID: 17437118. 
17. Gómez-Murillo SY, Solórzano-Morales SA, Macías Avilés H (2014). Siamese omphalopagus: presentation of a case. Acta Pediat Mex; 35: 469-476.

18. O'Brien P, et al (2015). Prenatal diagnosis and obstetric management. Semin Pediatr Surg [Internet]; 24 (5): 203-6. http://dx.doi.org/10.1053/j.sempedsurg.2015.06.002.

19. Baken L, et al (2013). Diagnostic Techniques and Criteria for FirstTrimester Conjoined Twin Documentation: A Review of the Literature Illustrated by Three Recent Cases. Obstet Gynecol Surv; 68 (4): 305-311.
20. Fallon S, Olutoye O (2018). The surgical principles of conjoined twin separation Semin Perinatol 2018; 42 (6): 386-392. doi: 10.1053 / j.semperi.2018.07.013. Epub.

21. Trost JG Jr, Lin LO, Clark SJ, Khechoyan DY, Hollier LH Jr, Buchanan EP (2016). Separation of Thoraco-OmphaloIschiopagus Conjoined Twins: Surgical Planning, Management, and Outcomes. Plast Reconstr Surg; 138 (5): 1064-1072. doi: 10.1097 / PRS.0000000000002660.PMID: 27783004.
This work is licensed under Creative Commons Attribution 4.0 License

To Submit Your Article Click Here: Submit Article

DOI: $10.31579 /$ jnmir.2021/005
Ready to submit your research? Choose Auctores and benefit from:

* fast, convenient online submission

* rigorous peer review by experienced research in your field

* rapid publication on acceptance

* authors retain copyrights

* unique DOI for all articles

* immediate, unrestricted online access

At Auctores, research is always in progress.

Learn more www.auctoresonline.org/journals/new-medicalinnovations-and-research 